\title{
東海豪雨における庄内川の洪水解析 ANALYSIS OF FLOOD OF THE SHOUNAI RIVER DUE TO THE HEAVY RAIN IN TOKAI DISTRICT
}

\author{
武田 誠 $1 \cdot$ 松尾直規 $2 \cdot$ 山中威士 ${ }^{3} \cdot$ 山口義一 $4 \cdot$ 中村昌充 4 \\ Makoto TAKEDA, Naoki MATSUO, Takeshi YAMANAKA \\ Yoshikazu YAMAGUCHI and Akimiti NAKAMURA \\ 1正会員 博士 (工) 中部大学講師 工学部土木工学科（テ487-8501 愛知県春日井市松本町1200） \\ 2フェロー 工博 中部大学教授 工学部土木工学科（同上） \\ 3学生会員 中部大学大学院 工学研究科 建設工学専攻 (同上) \\ 4非会員 中部大学 工学部土木工学科（同上）
}

\begin{abstract}
Sufficient investigation of flood flow is very important to protect an urban area from the flood disaster. Because flood flow is boundary condition for analysis of the overland flood flow, flood flow must be simulated in detail. In this study, the flood flow situation in the SHOUNAI River due to the heavy rain in Tokai district is simulated. This model consists 2D model for sea region and 1D model for river. Though the problem of roughness coefficient remains unsolved, the computed results show good agreement with the observed water level. The control effect of Otai retarding basin in the SHOUNAI River is evaluated targeting heavy rain in Tokai district. It is shown that the control volume of Otai retarding basin is very small against the discharge of the SHOUNAI River during the Tokai heavy rain, there fore, the height of dike for Otai retarding basin must be evaluated for peak-cut.
\end{abstract}

Key Words : Flood analysis, SHOUNAIi River, Tokai heavy rainfall, Otai retarding basin Numerical analysis model

\section{1.はじめに}

平成12年 9 月11日から12日にかけて，東海地方では台 風14号及び秋雨前線の影響により，未曾有の集中豪雨に 見舞われた. 名古屋地方気象台では, 総雨量 $567 \mathrm{~mm}$, 時 間雨量 $93 \mathrm{~mm}$ を記録した。これは, 年間総雨量の 3 分の $1 に$ 当たる量である.この記録的な集中豪雨で, 愛知県内で は水防警報が発令され，新川・天向川では危険水位（計 画高水位）を超える過去最高の水位を記録した，特に被， 害が大きかったのは新川で, 新川の破堤個所は, 河口か ら16 k m地点, 左岸側の名古屋市西区あし原町であった.

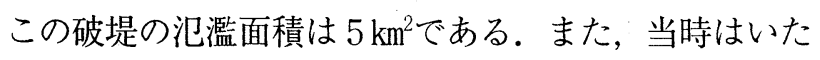
るところで内水による汇濫災害が生じており, 交通など の都市機能が麻痺するなど, 都市の水災に対する脆弱性 が浮き彫りにされた．東海豪雨による東海地方の人的被 害は死者 9 名, 建物被害は全・半壊及び一部破損は 269 棟, 床上浸水は 26,922 棟, 床下浸水は 42,060 棟である. これは, 昭和34年の伊勢湾台風以来の大規模な浸水被害 となった12).
新川破堤による大規模浸水のように，外水汇濫を対象 とする場合，河川流はその境界条件となる．また，当時 大きく広がっていた下水道の排水不良による内水汇濫を 検討する場合でも，河川水はポンプ排水に影響を与える ため，その状況をとらえておく必要がある。したがって， 東海豪雨時のさまざまな汇濫災害を再現して各種治水施 設の効果を検討するためには，まず，河川流を適切に解 析する必要がある.

これまで，さまざまな氾濫解析法が提案・構築されて いるが，そのなかでも都市構造物を適切にモデル化し， 詳細に汇濫水の拡がりを再現できるモデルとして, 川池 ら ${ }^{3)}$ の汇濫解析モデルが挙げられる。これは, 河川を特 性曲線法を用いた一次元解析で解き, 山地領域, 下水道, 氾濫域を統合的に解くモデルである。著者らもこのよう な解析モデルの開発を目指し研究を行っている. 本報で はその基礎モデルとして河川の洪水解析モデルを作成し、 東海豪雨時の庄内川の流況について解析を行ったのでそ の結果について示す。 また，小田井遊水地（河口から約 
$17 \mathrm{~km}$ ）の影響も検討しており，その効果についても言及 する.

\section{2. 数值解析}

\section{1 支配方程式}

本解析モデルは名古屋市を中心とする領域を対象とし， その周辺の河川, 海域の水理現象を再現するモデルであ る. 洪水のみを対象とする場合は, 河川のみを考慮すれ ばよいが，河口に水位観測所がない場合もあり，また， 高潮，津波なと外洋性の汇濫災害に対しても検討を加え たいため，海域を含めてモデル化している，河川域には 一次元不定流モデルを用い，それぞれの河川の合流・分 流を考慮した。 また，海域には，長波近似を施した平面 二次元不定流モデルを用いている.

1) 河川の取り扱い

河川流の解析には, 以下の連続式とエネルギー方程式 を用いた。

$\frac{\partial A}{\partial t}+\frac{\partial Q}{\partial x}=0$

$\frac{\beta}{g} \frac{\partial u}{\partial t}+\frac{\alpha u}{g} \frac{\partial u}{\partial x}+\lambda \cos \theta \frac{\partial h}{\partial x}-\sin \theta+\frac{n^{2} u|u|}{R^{4 / 3}}=0$

ここに, $A$ : 流水断面積, $Q$ : 流量, $x$ : 流下方向 にとった座標, $t$ : 時間, $u$ : 断面平均流速 $(=Q / A)$, $h$ : 水深, $g$ : 重力加速度, $\theta$ : 河床勾配, $\rho$ : 密度, $R$ : 径深, $n$ : マニングの粗度係数, $\alpha$ : エネルギー 補正係数, $\beta$ : 運動量補正係数, $\lambda$ : 圧力分布補正係 数である.ここで, $\alpha, \beta, \lambda$, は1とした.

2 ) 海域の取り扱い

海域での解析には平面二次元解析法を適用する. 基礎 方程式は以下の連続式と運動量方程式である.

$$
\begin{aligned}
& \frac{\partial h}{\partial t}+\frac{\partial M}{\partial x}+\frac{\partial N}{\partial y}=0 \\
& \frac{\partial M}{\partial t}+\frac{\partial u M}{\partial x}+\frac{\partial v M}{\partial y}=-g h \frac{\partial h}{\partial x}-\frac{h}{\rho} \frac{\partial P_{0}}{\partial x} \\
& +\frac{\partial}{\partial x}\left(\varepsilon_{x} \frac{\partial M}{\partial x}\right)+\frac{\partial}{\partial y}\left(\varepsilon_{y} \frac{\partial M}{\partial y}\right)+\frac{\tau_{s x}}{\rho_{w}}-\frac{\tau_{b x}}{\rho_{w}}+f N \\
& \frac{\partial N}{\partial t}+\frac{\partial u N}{\partial x}+\frac{\partial v N}{\partial y}=-g h \frac{\partial h}{\partial y}-\frac{h}{\rho} \frac{\partial P_{0}}{\partial y} \\
& +\frac{\partial}{\partial x}\left(\varepsilon_{x} \frac{\partial N}{\partial x}\right)+\frac{\partial}{\partial y}\left(\varepsilon_{y} \frac{\partial N}{\partial y}\right)+\frac{\tau_{s y}}{\rho_{w}}-\frac{\tau_{b y}}{\rho_{w}}-f M
\end{aligned}
$$

ここに, $u, v$ : それぞれ $x, y$ 方向の断面平均流速, $h$ : 水深, $M, N$ : それぞれ $x, y$ 方向の流量フラックス $(M=u h, N=v h), H$ : 水位, $P_{0}$ : 大気圧, $\tau_{s x}, \tau_{s y}$ : 水表面でのせん断応力の $x, y$ 成分, $\tau_{b x}, \tau_{b y}$ : 水底面で のせん断応力の $x, y$ 成分, $g$ : 重力加速度, $\varepsilon_{x}, \varepsilon_{y}$ : $x, y$ 方向の渦動粘性係数, $f$ : コリオリのパラメータで ある。
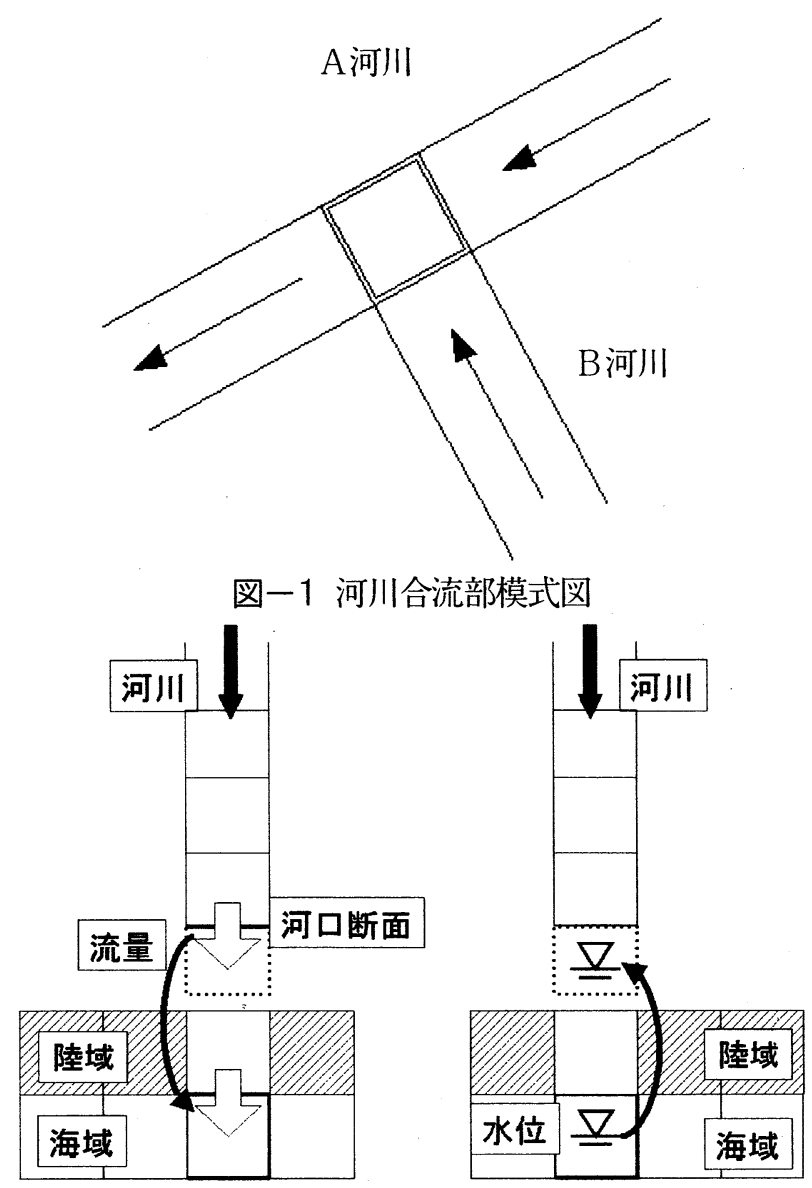

図一2 河川域と海域の合流部模式図

水表面でのせん断応力 $\tau_{s x}, \tau_{s y}$ は以下の式で表される.

$\tau_{s x}=\rho_{a} \gamma^{2} W_{x} \sqrt{W_{x}^{2}+W_{y}^{2}}$

$\tau_{s y}=\rho_{a} \gamma^{2} W_{y} \sqrt{W_{x}^{2}+W_{y}^{2}}$

ここに $\rho_{a}$ : 空気の密度, $\gamma^{2}$ : 水表面における係数, $W_{x}, W_{y}:$ それぞれ高度 $10 \mathrm{~m}$ の風の $x, y$ 方向成分である. また，底面のせん断応力 $\tau_{b x}, \tau_{b y}$ は以下の式で表される.

$\tau_{b x}=\rho g n^{2} M \sqrt{u^{2}+v^{2}} / h^{4 / 3}$

$\tau_{b y}=\rho g n^{2} N \sqrt{u^{2}+v^{2}} / h^{4 / 3}$

ここに, $\rho$ : 水の密度, $n$ : マニングの粗度係数であ る.

3 ）河川合流・分流の取り扱い

図ー1のようにA河川にB河川が接続している場合, A河川は(1)式，(2)式を用いて解かれるが，B河川が合 流している場所ではB 河川下流端の流量を(1) 式の右辺 に横流入量として与える. B河川下流端ではA河川合流 部の水位を用いて運動方程式を解いている。

4 ）河川域と海域の合流部の取り扱い

図一2のように接続を考え, 河川からの流量を海域の 接続格子に与え, 河川下流端の流量は接続格子の水位を 用いて計算している. 


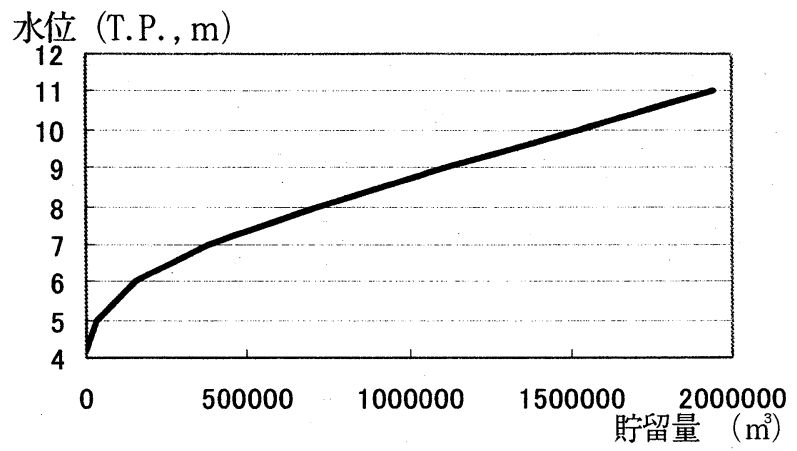

図一3 小田井遊水地販留量一水位関係図

5) 数值解析法

数值解析には差分法を用い, 河川の一次元解析, 海域 の二次元解析ともに, 時間項には前進差分, 移流項には DONORスキーム，その他の項には中央差分を用いた。

6) その他の取り扱い

その他，本解析では洗堰，小田井遊水地，庄内川・新 川河口域の背割堤部における越流を考慮した。

洗堰においては，その越流量の算定式として次の越流 公式が求められている. 解析では隣接断面における庄内 川水位から越流量を算出し，その量を連続式で考慮した。 $Q=\mu B h_{1} \sqrt{2 g h_{1}}$

ここで, $Q$ : 越流量, $\mu$ : 完全越流における係数 $(\mu=0.35), B$ : 越流幅 (56m)， $h_{1}$ : 越流水深であり， $H$ を庄内川の洗堰隣接格子の水位, $H_{T A}$ を洗堰の天端 高 $(9.12 \mathrm{~m})$ とすると $h_{1}=H-H_{T A}$ で表される.

小田井遊水地に扔いては，その貯留量と水位の関係が 図一3のように求められている ${ }^{4)}$. 解析では越流箇所に おける流量を求め, その量を庄内川の越流箇所隣接格子 の連続式で考慮した．遊水地内水位は流入する流量から その貯留量を求めて算出した. 用いた越流公式は以下の とおりである。

$$
\begin{aligned}
& h_{1} / h_{2}>2 / 3 \text { の場合 } Q=\mu B h_{1} \sqrt{2 g h_{1}} \\
& h_{1} / h_{2} \leqq 2 / 3 の \text { 場合 } Q=\mu^{\prime} B h \sqrt{2 g\left(h_{1}-h_{2}\right)}
\end{aligned}
$$

ここに, $\mu=0.372, \mu^{\prime}=0.9672$ であり, 小田井遊水地 の水位と庄内川の流入箇所隣接格子の水位加越流水深 を求め，大きい方を $h_{1}$ ，小さい方を $h_{2}$ としている. ま た，庄内川から小田井遊水地へ流入する場合を正として 取り扱った。

庄内川・新川の間の堤防は河口から約 $3.0 \mathrm{~km}$ まで背割 堤となっているため，水位によっては庄内川から新川へ， または，その逆へと水が移動する。そその効果をここでは 考慮し, 河口から $3.0 \mathrm{~km}$ の間で越流量を算出して, 対応 する庄内川・新川の流入箇所隣接格子において連続式で その量を増減させた。

7）計算領域

図一5のような名古屋市を囲む領域を計算領域として 設定した。また，海域にはそれぞれの洪水流の影響が反 映されるようにかなり大きめの領域を設定している.

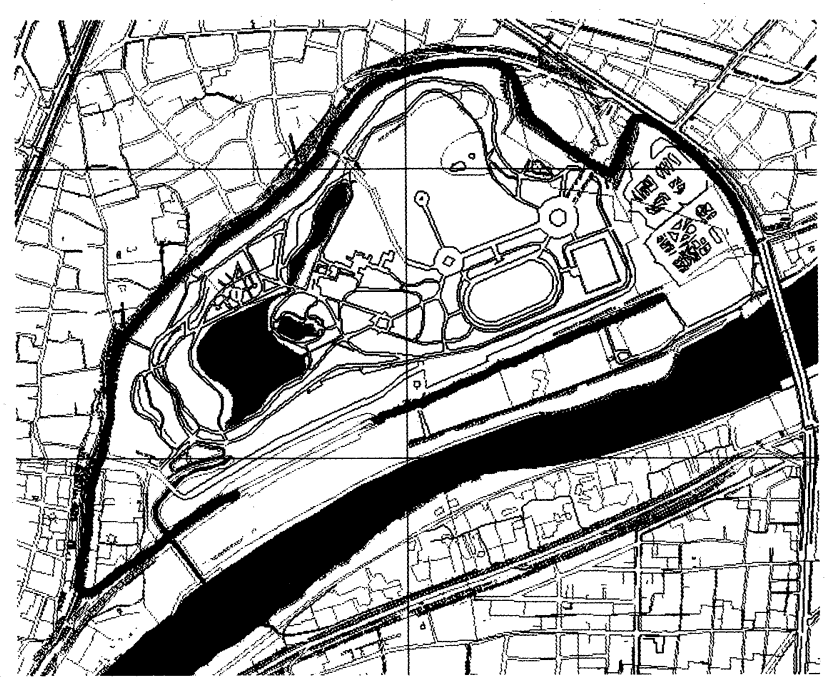

図一～小田井遊水地形状
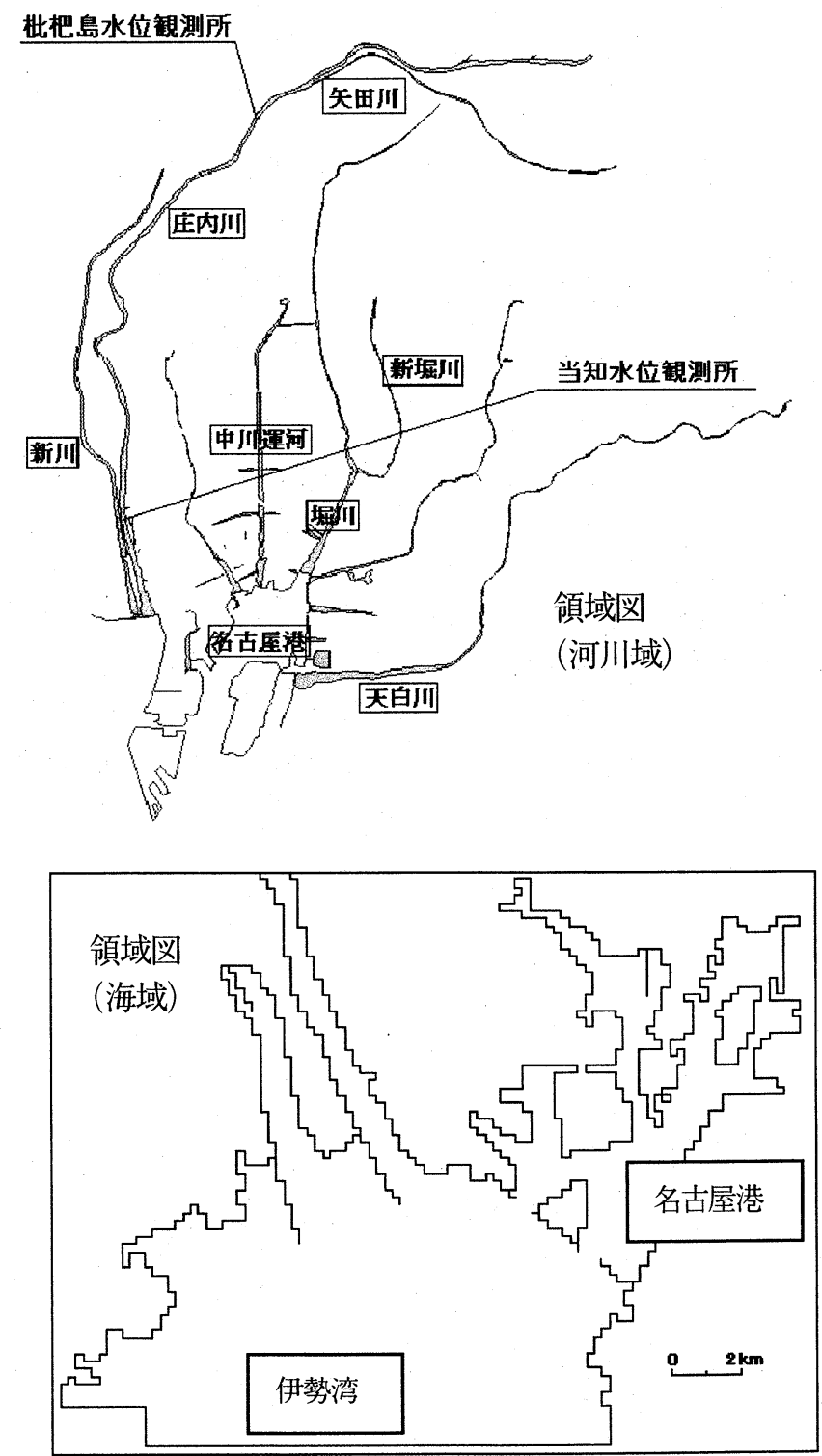

図-5 計算領域 


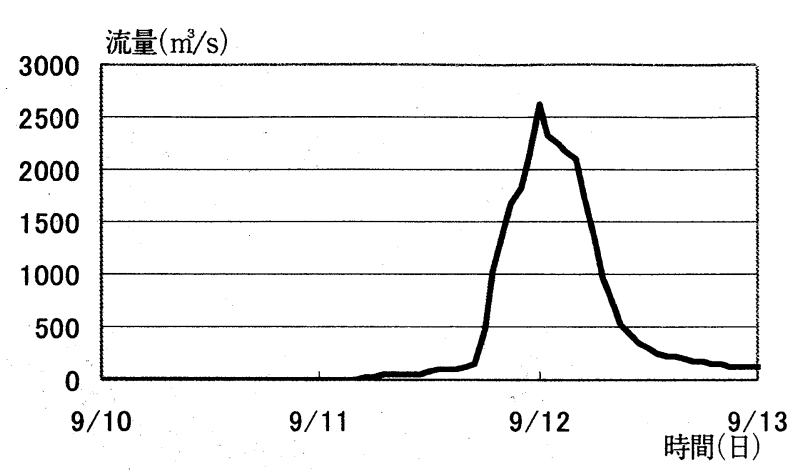

図-6 庄内川流量（志段味水位観測所）

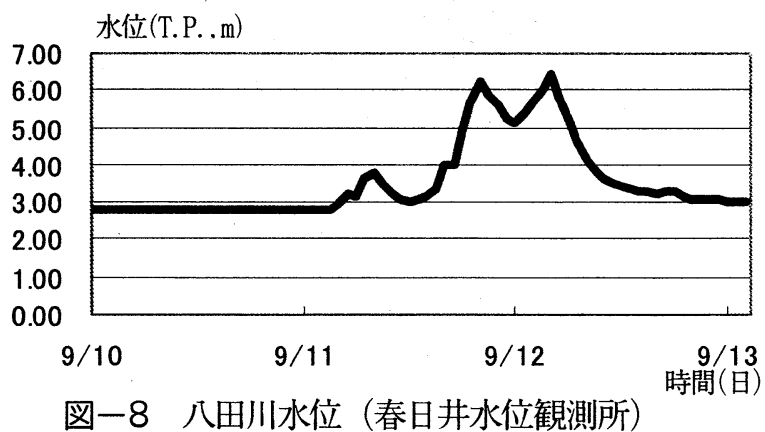

\section{3. 東海豪雨時の庄内川・新川の再現計算}

\section{1 計算条件}

境界条件として庄内川，矢田川には図一6，7に示す 流量を与えた。ただし，この值は観測された水位より H -Q曲線を用いて求められたものである ${ }^{4)}$ 。八田川には 春日井水位観測所で得られた水位を与えた。 また，海域 には四日市と常滑の推算天文潮を平均して平面 2 次元解 析の海側開境界条件(図一9)として与えている.

粗度係数に関しては，試行錯誤的に 0.02 と0.03を用い て計算を行っている。 また，粗度係数 0.03 の計算に関し ては $10 \mathrm{~km}$ 地点まで粗度係数を $0.02 に$ 变更した場合も計算 を行っている.

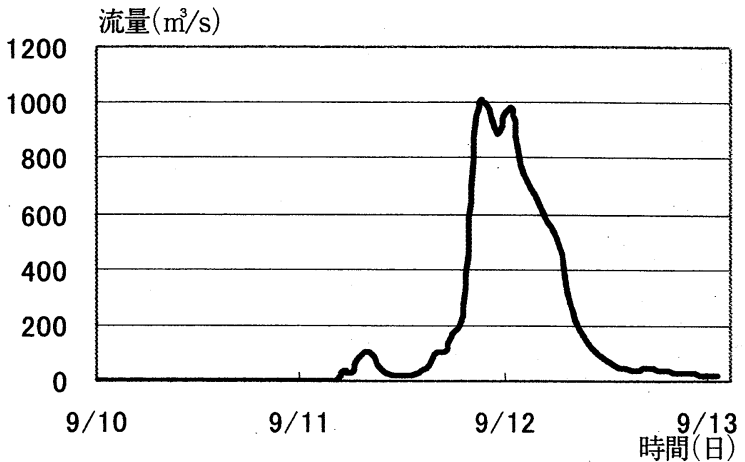

図-7 矢田川流量（瀬古水位観測所）
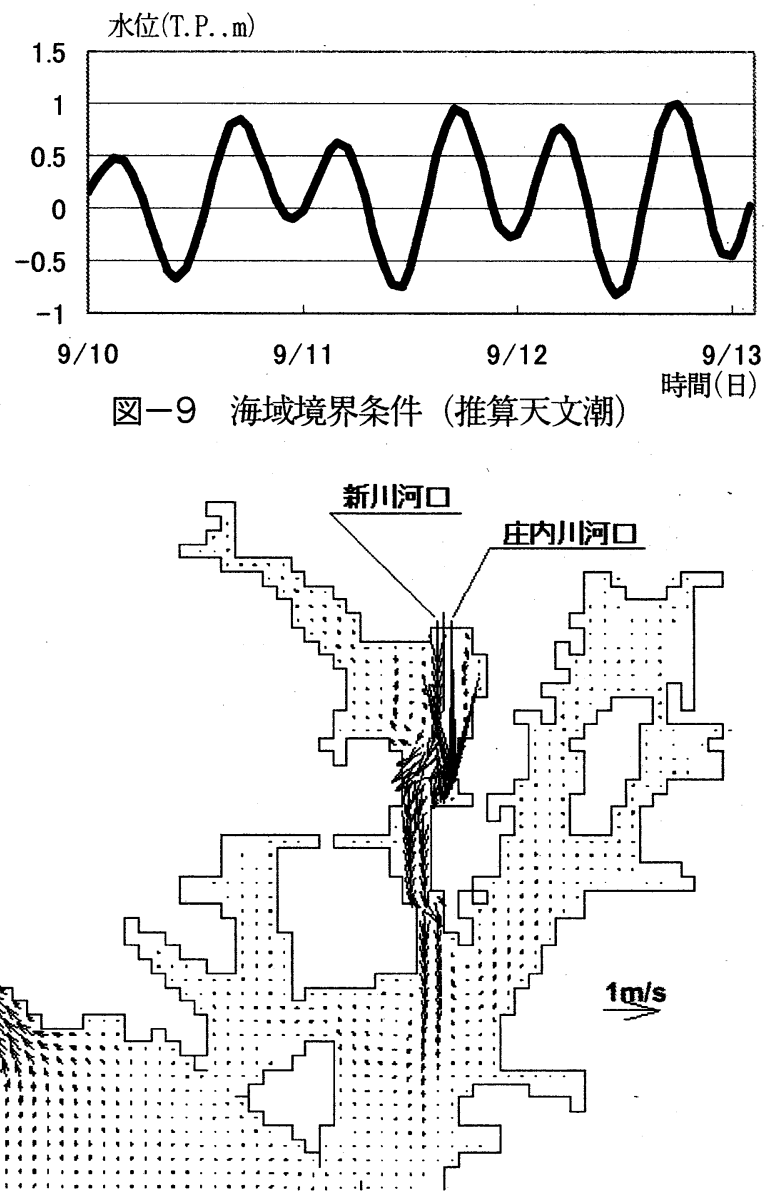

図-10 洪水時の海域の流速（名古屋港付近）

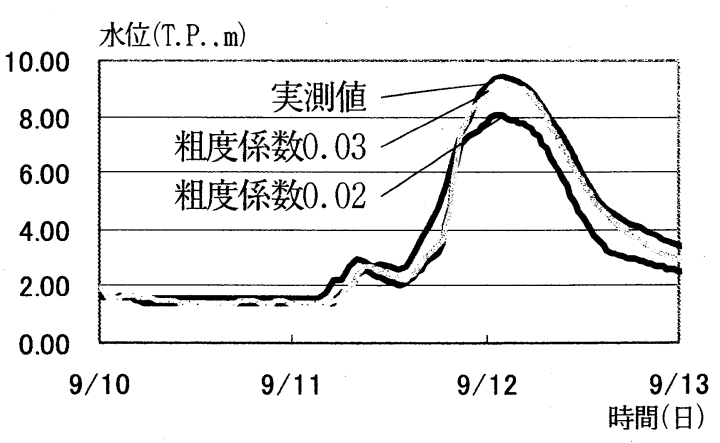

図-12 枇杷島水位観測所での水位の比較 


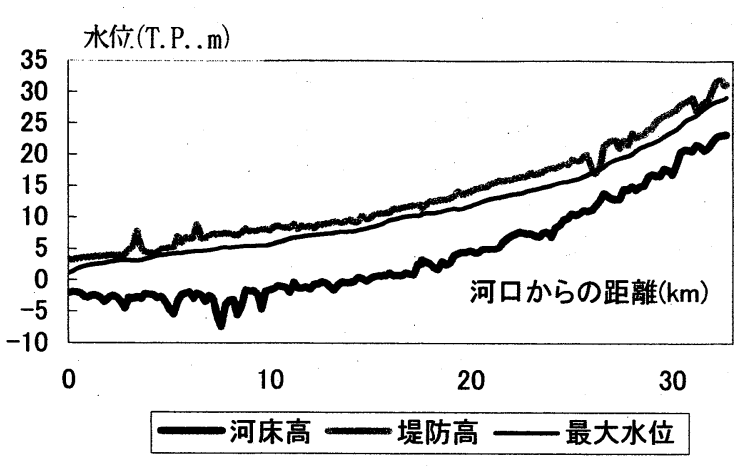

図-13 庄内川水位綐断分布図
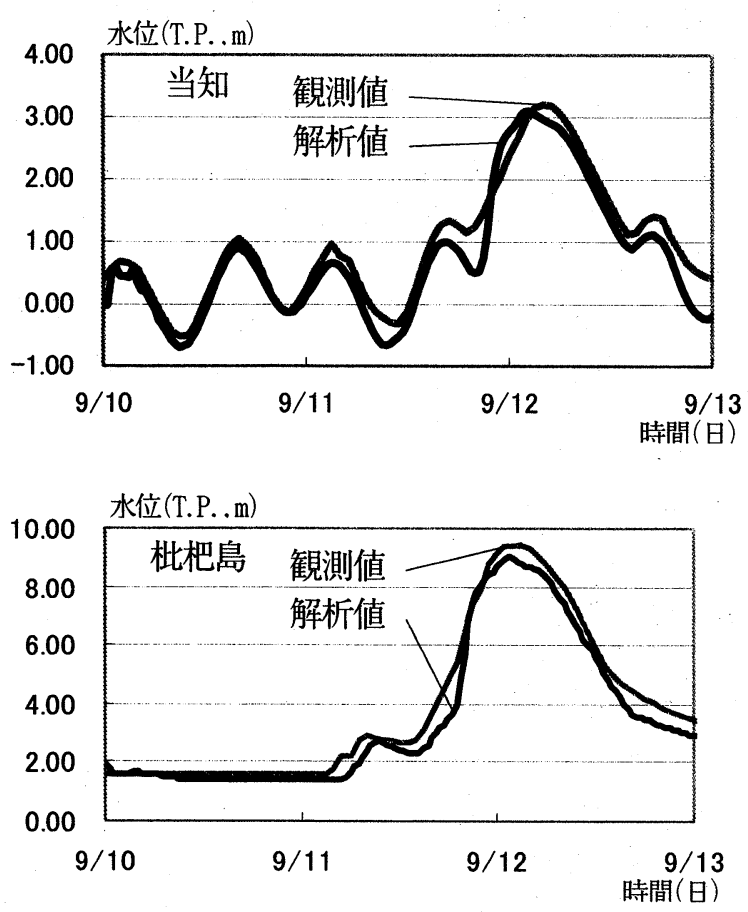

図一14 粗度係数を変化させた場合の水位

\section{2 計算結果及び考察}

図一10は洪水ピーク時における海域での流速分布を 示したものである. 図より庄内川, 新川での流入が名古 屋港内での水の動きに大きく影響を与えていることが見 られる. また干潮時, 満潮時においても河口との接続部 で流出入が見られるため河川と海域との接続はおおおね 良好であるといえる。

図一11,12は当知水位観測所（河口から2.9km），枇 杷島水位観測所（河口から $15.7 \mathrm{~km}$ ) での実測水位と計算

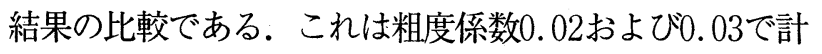
算した結果である. 本図から, 粗度係数が $0.02 の$ 場合は, 当知で水位の計算值が観測值と同程度であるが, 枇杷島 では観測值が観測値よりもかなり小さいことが分かる. また, 粗度係数が 0.03 場合は, 枇杷島での水位の計算 值か観測值と一致しているが, 当知では一致していない. したがって, 粗度倸数 0.03 とし, 試行錯誤的に河口から $10 \mathrm{~km}$ までの粗度係数を 0.02 とした計算を行った。結果を
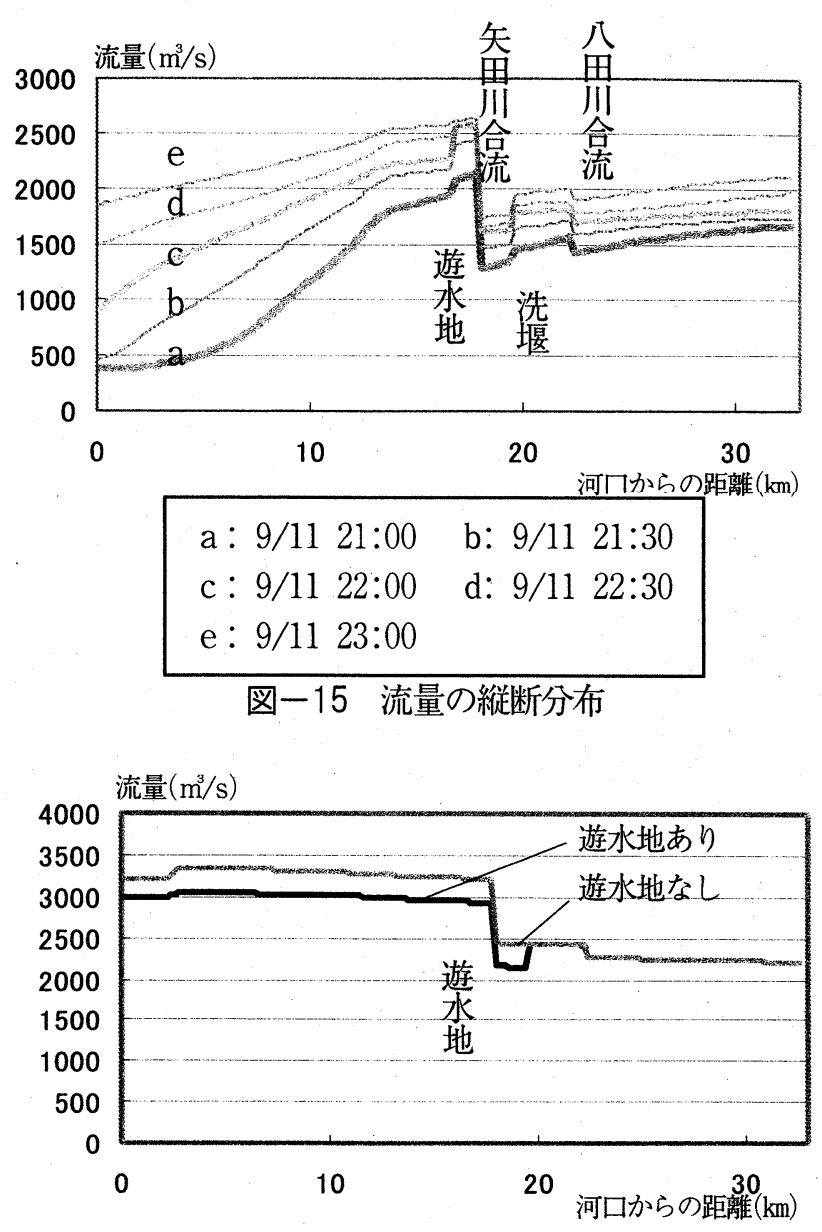

図一16 小田井遊水地・洗堰の有無による流量の变化

図ー14に示す．本図から粗度係数を変化させたことで 解析值か観測值に近づいていることが分かる。したがっ て, 粗度係数を適切に与えることにより, 現実の水位変 動を再現することが可能になるものと思われる．河口に おける流れの様子や全体的な水位変動を見ても矛盾する ところは無く，本解析モデルが妥当であるといえる.

また，東海豪雨時の庄内川の水位変動を良く表してい た粗度係数を変化させた場合の最大水位の縦断分布を図 -13 に示す. 本図から約 $4.5 \mathrm{~km}$ のころで水位が堤防に 近づいている様子が分かる。ここは一色大橋付近であり 東海豪雨当時非常に危険視された箇所であり，実際の現 象と一致している。

これらのことから, 本解析モデルでは, 東海豪雨時の 庄内川の流況をある程度再現することができ，本解析モ デルの妥当性が示された。

\section{4. 小田井遊水地の効果}

つぎに，小田井付近の枇杷島で水位の計算值と観測值 が比較的一致していた粗度係数 0.03 の場合を用いて, 小 田井遊水地の効果について検討する. 図一15に流量の 


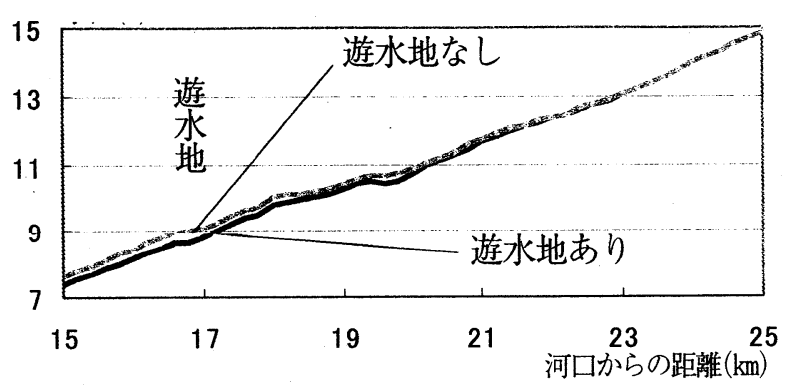

図一17 小田井遊水地の有無による水位の変化

縦断分布を示す．本図から対象とした流れ場が不定流で あるため流量の縦断変化が存在することが分かり，八田 川からの流入，洗堰による流出，矢田川からの流入，小 田井遊水地への流出が示されている. 本図から流量が増 加し，水位が上昇すると小田井遊水地へ流れ込み，その 分本川流量が減るが，遊水地が満水となれば流れ込まな いため本川流量の減少がなくなる様子を示している．ま た，図一16に小田井遊水地・洗堰の有無による流量の 変化を示す. 河口水位がピークとなる9月12日2:30の時 のものである. 本図から，洗堰への流出分だけ流量が低 下していることが分かる．図ー15より遊水地は常に十 分に機能するというわけではなく，流入する場合には機 能するが，遊水地が満杯になると機能しなくなる．図一 17には小田井遊水地・洗堰の有無による水位の変化を 示す. 本図から数十七ンチのオーダーで水位が低下して いる様子が分かる。これは，東海豪雨時の流量が大きす ぎるため，水位が十分に低下することはなかったものと 考えられる。

本計算では, 河口水位最大時間の約 5 時間前に遊水地が 満水になっていた。 このことは, 東海豪雨時において遊 水地がピークカット機能を持たなかったことを意味する. したがって，越流堤の天端高の検討など，遊水地の効果 的な運用法を検討する必要があるといえる．また，治水 対策としてはひとつの事業で完成するものではなく, 総 合的治水対策に見られるように複合的な対策を行うこと
で治水効果を上げることが今日的な対策であるといえ る.したがって，このような観点から庄内川およびそ の流域にわたる治水的検討が必要であろう.

\section{5.おわりに}

本研究では, 東海豪雨を再現するための第一段階と して, 庄内川の洪水流解析を行い, 観測值との比較か らモデルの妥当性を検証した。

また，小田井遊水地の効果を検討し，流量で見た場合 に貯留施設としての効果が理解でき，その機能が発揮す る時期と満水となり機能が発揮できない時期とに分かれ ること, さらに, 本計算の場合, 河口水位が最大となる 時間よりも約 5 時間前に満水となっており，東海豪雨時 にはピークカット効果は果たせなかったことなどが分 かった。

今後は河道内洪水流の解析精度を向上させるとともに, 汇濫解析に拡張し, 東海豪雨時の水災害現象について解 析を行いたいと考えている.

参考文献

1）建設省中部地方建設局 庄内川工事事務所：平成12 年 9 月 12 日庄内川出水状況（速報）

2 ）愛知県建設部：平成12年 9 月 11 日 12 日 豪雨災害 (台風14号，秋雨前線）

3 ）川池健司 - 井上和也 - 戸田圭一・坂井広正 - 相良亮 一：低平地河川流域における内水氾濫解析法とその 寝屋川流域への適用，水工学論文集，第46巻， pp. 367-372, 2002.

4) 財団法人 河川情報センター: 平成 13 年度庄内川洪 水予測および河川管理システム高度化検討業務 報 告書, 2002.

（2002. 9. 30受付） 